\title{
Implementation of Auditing in Zakat Institutions: Case studies of BAZNAS Riau and Pekanbaru
}

\author{
Devi Megawati ${ }^{1}$
}

\begin{abstract}
This paper examines the implementation of auditing in Zakat Institutions with a case study in BAZNAS Riau Province and BAZNAS Pekanbaru. Nowadays, the government and citizen's attention for zakat management has become so high. Therefore, there are publications of rules about the obligation of zakat Institutions to make the report which, then, is an object to be audited. The researcher interviewed some regarding this topic, such as the Commisioner Head and Manager of BAZNAS Riau province and BAZNAS Pekanbaru and some staff of the Ministry of Religion who are in charge of zakat. The findings show the high attention of important role of internal auditor in zakat institutions. In the case at BAZNAS Pekanbaru, a team of internal auditors has been formed in 2017. The internal auditing activities can be the starting point for the external auditing activity. External auditing in zakat institutions industry facing many challenges such as waiting the release of technical rules of sharia audit from Ministry of Religious Affairs. The paper contributes to the better governance for zakat institutions to increase the trust of moslems especially muzakki in Riau province.
\end{abstract}

Keywords: Zakat institutions, Internal audit, sharia audit, financial audit

\begin{abstract}
Abstrak. Penelitian ini bertujuan untuk mencari tahu mengenai implementasi proses audit di lembaga pengelola zakat dengan studi kasus di BAZNAS propinsi Riau dan BAZNAS Pekanbaru. Akhir-akhir ini pemerintah dan masyarakat memiliki perhatian yang tinggi terhadap pengelolaan zakat. Hal ini dengan dikeluarkannya aturan mengenai kewajiban lembaga pengelola zakat untuk membuat laporan keuangan dimana laporan keuangan tersebut harus diaudit. Peneliti telah melakukan wawancara kepada Ketua komisioner dan manajer di BAZNAS Propinsi dan BAZNAS Pekanbaru. Selain itu juga beberapa staf di Kementerian Agama yang mengurusi bagian zakat. Hasil penelitian ini adalah telah ada perhatian dari pengelola zakat akan pentingnya auditor internal pada kasus di BAZNAS Pekanbaru dimana mereka telah membentuk tim internal auditor walaupun masih bersifat sementara. Dengan adanya internal auditor menjadi langkah awal dalam proses audit eksternal. Sedangkan audit eksternal pada lembaga pengelola zakat menghadapi beberapa tantangan diantaranya menunggu aturan teknis tentang audit syariah dari kementerian agama. Penelitian ini dapat berkontribusi bagi tata kelola yang lebih baik bagi lembaga pengelola zakat sehingga dapat meningkatkan kepercayaan muslim, terutama muzakki di Propinsi Riau.
\end{abstract}

Kata kunci: Lembaga pengelola zakat, audit internal, audit syariah, audit keuangan

\footnotetext{
${ }^{1}$ Faculty of Sharia and Law, UIN Sultan Syarif Kasim, Indonesia | devimegawati@uin-suska.ac.id
} 


\section{Introduction}

Simply, zakat can be considered as the religion tax (Saad et al, 2014). Zakat literally means 'the cleanser' because zakat can cleanse the wealth and soul of the muzakki (zakat payees). Zakat by common terminology means the expense on a specific part of our wealth (Qardawi, 2004) in a specific condition for 8 classified groups of zakat receipients according to Qur'an.

"The alms are only for the Fuqara' (the poor), and Al-Masakin (the needy) and those employed to collect (the funds); and to attract the hearts of those who have been inclined (towards Islam); and to free the captives; and for those in debt; and for Allah's Cause, and for the wayfarer (a traveler who is cut off from everything); a duty imposed by Allah. And Allah is All-Knower, All-Wise." (At-Taubah [9]: 60)

Zakat is one of the five pillars of Islam, in which paying zakat not only for showing our devotion to Allah SWT, but also can be the solution to our social-economic problem such as reducing poverty.

The empirical results suggest that zakat spending has the ability to influence economic activities, represented by the real GDP, suggesting that zakat could be employed as an important tool to stimulate economic growth. This implies that zakat could also reduce the inequality of income distribution and wealth, decrease the gap between rich and poor (Yusoff, 2012).

Zakat has a mission to change the status of (mustahiq) zakat recipients to become the (muzakki) zakat payees. In order to do that mission, zakat distributions program should be following the era and customized as needed (Nurzaman, 2010). Some of the distribution programs are giving the financial capital/support and skill for small business, supporting on medication and also giving scholarship.

In the era of Rasulullah SAW, zakat and all of the national incomes were collected and managed in Baitul Maal. Baitul Maal it self is similar to today's Ministry of Finance. But sadly, in some moslem countries such as Indonesia, zakat is not managed by Ministry of Finance. It is managed by the Ministry of 
Religious Affairs, instead. This is because zakat is not included in fiscal system; it only included in voluntary system (Wahab, 2011).

In 1999, the government issued the first zakat law. In that approved regulation, it can be found about two types of zakat institutions; BAZNAS (Badan Amil zakat Nasional) and LAZ (lembaga Amil zakat). The difference of these two organizations is that BAZNAS is formed by the government's initiative and LAZ is formed by citizen's initiative. The other differences is that BAZNAS consists of BAZNAS RI in Jakarta, regional BAZNAS (BAZNAS Province) and district BAZNAS (BAZNAS distric) in which each of them is autonomus. LAZ also consists of the central office and can form/build its branch offices one in each of the regions in Indonesia (KMA No. 333 in 2015). For example LAZ Nationality level can form branch office in each province. Permit of LAZ valid for up to 5 years and be extend.

However, there are so many Indonesian moslem who did not pay zakat to the zakat institutions. In 2010, the sum of zakat gathered is just 1.5 trillion rupiahs, but counting the potential of zakat in that year, it reached up to 217 trillion rupiahs (Firdaus, 2012). The huge gap between zakat's potentials and zakat realizations is the condition faced by zakat institutions. There are many factors causing the sum of zakat realizations smaller than zakat potentials. As indicated in the results of the research Norazlina (2011), many zakat programs are not effective yet, particulary in terms of zakat distributions. The informations about zakat distributions are not transparent to public.

In 2011, the government issued the regulation no. 23 in 2011 as the replacement for zakat regulation no.38 in 1999. In that new regulation, there is an obligation of zakat institutions to make the report, and that report should be audited. The audits that will be done are financial audit and sharia audit. Financial audit will be performed by public accounting office and shariah audit will be done by the ministry of religious affairs. The auditing process is one of the ways to make the information more transparent so that citizen and donators trust more and are willing to pay zakat through zakat institutions. 
This makes the researcher interested in conducting a research project toward the implementation of auditing process in zakat institutions. In this paper, BAZNAS Riau Province and BAZNAS Pekanbaru are the cases study. From 13 BAZNAS in Riau province, BAZNAS Riau province and BAZNAS Pekanbaru are located in the big city so the access to the information is easier. Moreover, if we look at the sum of zakat collected in BAZNAS Pekanbaru, it shows that the performance improves every year, and for BAZNAS Riau province got awarded best governance from all BAZNAS in Indonesia in 2017. Meanwhile, the other Zakat Institutions type like LAZ will be the case study in the following research project.

In collecting the data, the researcher used interview and documentation (in a form of annual report). The head and manager of BAZNAS and also the staff of Ministry of Religion in charge of zakat were taken as the informen.

Next, this paper will explain about evolution of zakat management, development of zakat institution in Indonesia, zakat standard accounting, method, internal audit, financial audit, syariah audit, and conclusion.

\section{Literature Review}

\section{Zakat in the Time of the Prophet and Khulafaur Rashidins}

The issue of obligation to pay zakat revealed in $623 \mathrm{BC}$ or the $2^{\text {nd }}$ period after Rasul moved or hijrah from Mecca to Madinah. Before that, zakat had never been obligatory so people did it voluntarily without details and accounting (Qardawi, 2004). Prophet Muhammad as the head of the nation gathered all the income, from zakat, kharaj (land tax), ghanimah (spoils of war) in Baitul Maal before being distributed. Baitul Maal had been formed since Badar war where moslem won in that war and got ghanimah (Gusfahmi, 2007). If we look at the history, therefore the duty to collected zakat is the authority of the leader as we could see in Rasulullah SAW according to Qur'an (AtTaubah [9]: 103).

The important role of the leader in collecting zakat is due to the fact that sometimes we need the coersive power in some cases. Like in the caliph 
Abubakar's period, he fought with a group of people who was not willing to pay zakat. Zakat management always improves from time to time, but mainly, the duties itself consists of doing sensus towards muzakki (zakat payer) and their kinds of wealth, counting how much out of the wealth someone has to pay for zakat, doing some sensus towards the mustahik (zakat recipients), analysing their need for a better quality of life, and also counting the sum of support for each mustahik. This regulation was also continued by the caliphs after Muhammad SAW passed away.

These four caliph are considered as Khulafaur Rasyidin because they were the first four people who led moslems after Rasulullah SAW passed away. They were also the devoted best friends who accompanied Rasulullah until the end of his life. These are the caliphs' contribution in each of their time according to the book (Gusfahmi, 2007).

Abu Bakar as Shiddiq became the caliph after Rasulullah passed away. Because of that, he faced so many problems like the appearance of fake prophets and also the rejection from some moslems to pay for zakat. Then, he makes the statement to fight those people who did not pay for zakat because they had violated Allah and Rasul's rules.

In his period, Chaliph Umar Bin Khatab successfully collected the national income, including zakat in total of 18 millions dirham. Caliph Usman bin Affan contributed in the improvement of zakat management's administration, which, in his period there was a staff to count zakat and he appointed Zaid bin Tsabit as the supervisor of Baitul Maal Caliph Ali bin Abi thalib was very careful while doing zakat management. He would not take the financial support from Baitul Maal. He even donated 5,000 dirham every year to Baitul Maal.

\section{Development of Zakat Institutions in Indonesia}

Zakat's management in indonesia, as explained in the Ministry of Religious Affairs guide book (Kementerian Agama RI Direktorat Jenderal Bimbingan Masyarakat Islam , 2012), has divided its improvement into: 
Dutch's government published a regulation managing some practices in Indonesia, especially for islamic teachings that was known as Dutch's government ordanantie number 6200 on February $28^{\text {th }}$, 1905. The regulation stated that Dutch government would not interfere zakat's management problems and would give it all to moslem for doing it as far as it is appropriate with islamic teachings.

Although the independence of Indonesia was declared in 1945, it was just in 1951 the government under the Ministry of Religious Affairs issued a regulation letter number: A/VII/17367 about implementation zakat al-fitr. Next in 1964, the ministry also arranged a regulation about creating baitul maal as a zakat management insititution. Unfortunately, the draft had never had an opportunity to be proposed to the house of representatives.

In 1967, the draft of regulation about management of zakat was proposed to Indonesian House of Representatives with a letter number: MA/095/1968. The letter was also sent to social ministry and finance ministry. And the finance ministry suggested that issues related to zakat should only be managed by religious ministry's regulation. So, in 1968 the regulation number 4 in 1968 about creating BAZ (Badan Amil Zakat) was issued by the ministry of religious affairs. After that, BAZ was officially considered as zakat's fund distributor and based on the ministry's regulation number 5 in 1968 about creating baitul maal, it functions as a receipient or zakat collector. After a while, in 1991 there was a decision made by religion ministry and domestic affairs of ministry number 29 and number 47 about the development of amil zakat, infak, and sadaqah (BAZIS). Followed by the regulation of technical development on BAZIS in the ministry of domestic affairs instruction number 7 in 1998.

Reformation era happened when economy crisis surged Indonesia, and followed by the urge from the people to change president Soeharto who had already been in charge for over 30 years. Reformation era was defined as a form of freedom and change. This momentum was used to publish the first 
TIFBR | Tazkia Islamic Finance and Business Review

regulation about zakat, that is law number 38 in 1999. This regulation legalized two forms of official institutions for zakat management: BAZ and LAZ.

New paradigm inside the zakat management changed from the traditional to modern management. Zakat management was not proceeded as a side work. Instead, zakat institution would hire more educated and full time workers. Because of that, we can see that the institutions of zakat (BAZNAS and LAZ) have a program to collect zakat with marketing techniques like a modern company's and have an inovation program to empower mustahik like offering a scholarship, providing skills, giving business capitals, providing free health check up, building free schools and free clinics which all should suit to the mustahik's needs.

After 12 years of the law number 38 tahun 1999, zakat management definitely needs some improvements. Therefore, a new regulation is necessary to replace the law number 23 in 2011. New thing applied is about the audit as researchers' explanation in this research. The audit regulation can be found in the government regulation number 14 in 2014. This government regulation still contains some regulations from the old regulations of the religious ministry. Unfortunately, the regulation about religion (PMA) regarding audit has not been official yet and still in form of draft.

\section{Masterplan and Architecture of Zakat}

To reach good governance, BAZNAS has 3 strategies: First, Supervisor consist of 3 people from academician and zakat researcher. The supervisor has function to ensure BAZNAS operate allows the rules and sharia aspect. Second, Management team from permanent employee. Fit and proper test to ensure management team work professionally. Third, the government support fund to operate zakat and to sustaine system.

The main challenges for BAZNAS are to build good governance and prove that BAZNAS can work effectively and efficiently. Since zakat act 23 in 2011, BAZNAS not only collect and distribute zakat, but also control LAZ. LAZ 
should give their report to BAZNAS once in 6 months. We can see clearly in figure 1 below.

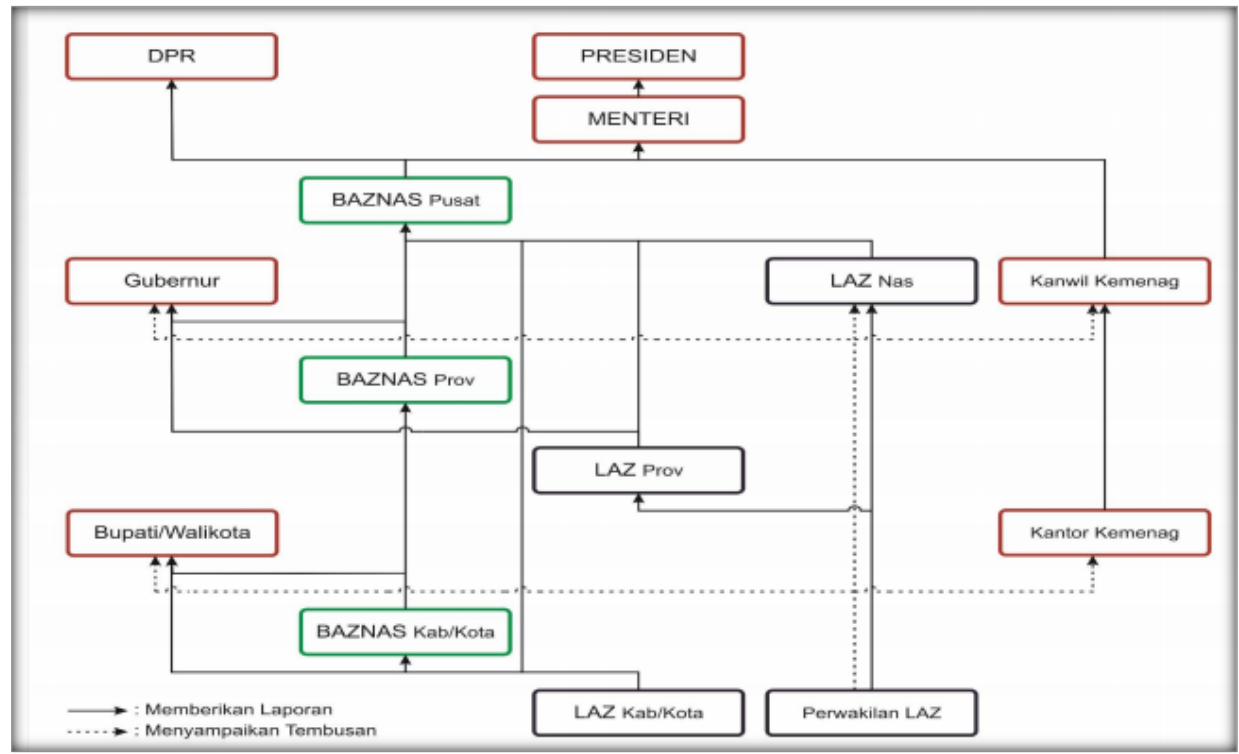

Figure 1. Zakat Institutions Structure

Governance of zakat management in Indonesia not yet settle. In masterplan and architecture of Islamic finance in Indonesia is arranged by BAPPENAS that in 3 years later BAZNAS as only institutions can collect zakat, and LAZ will be only distributed zakat. For BAZNAS and LAZ can take amil fund part to pay their operation.

This masterplan and architecture the same structure with zakat act in 2011. But LAZ was unaccepted and took option to judicial review of zakat act 23 in 2011 because this regulation marginalize of LAZ. In the first zakat regulation, between BAZNAS and LAZ is equal.

Government worried about too many LAZ in Indonesia because increase fraud potential. On the other hand some issue about amil (administrator) fund. Because of high activities in LAZ and government not support fund like BAZNAS, amil take many portion of zakat fund. The fairness portion not more than 1/8 zakat fund. Eventhough in Qur' an and sunnah (two source of Islamic principle) not explicit explanation about portion of each mustahik. For instance medical treatment program for poor and needy people. 
All of the expenditure such as doctor, medicine and amil include volunteer to be one packet distribution.

Actually, amil in LAZ have an opinion about BAZNAS that BAZNAS only supervision LAZ not take a part to manage zakat. When we use analogy that BAZNAS as BI (central bank) or OJK (Authority finance service) and LAZ as financial institutions. Zakat institution industry such as LAZ exist more than 10 years. Many moslem trust and to be customer or donatur regular in LAZ. According to Peraturan Direktur Jenderal Pajak Number PER-11/PJ/2017 about zakat institutions are legalize to collect zakat and their zakat can reduce tax are $23 \mathrm{LAZ}$ in Indonesia.

The accounting standards for zakat managers in Indonesia have been effective since 2009, which is statement of accounting standart for zakat No.109 (known as Pernyataan Standar Akuntansi Keuangan/PSAK 109). This standard is released by the Zakat Forum (FOZ) together with the Institute of Indonesian Accountant (IAI). Previously the standard used by zakat Institutions was statement of accounting standart for nonprofit organizations No.45 (PSAK 45). With these accounting standards; in PSAK 109, each zakat institutions financial report was comparable. In addition, this standard could also serve as an auditor's guidance in zakat institutions audit.

Statement of accounting standart for Islamic principle (PSAK sharia) in Indonesia, many adopted accounting standards are prepared by AAOIFI (Accounting and Auditing Organization For Islamic Financial Institution). AAOIFI was first established in 1991 in Bahrain. The organization aims to create standards for the Islamic finance industry. There are currently 94 standards produced by AAOIFI that have been adopted by more than 45 countries including Indonesia. Standards of Generally Accepted Accounting Principle (GAAP) that are usually used in conventional financial system is not suitable if being used in the Islamic financial system so that the presence of AAOIFI standards can answer the needs of the Islamic financial industry (Alexakis, 2009). 
TIFBR | Tazkia Islamic Finance and Business Review

Zakat standards were issued by AAOIFI called FAS (Financial Accounting Standard) No. 9/1998. In 2006, Malaysia also issued zakat accounting standards. The difference between these three accounting standards is that AAOIFI standards are reserved for Islamic banks and other Islamic financial institutions. Zakat accounting standards in Malaysia cover a wider business organization that is not only for Islamic banks and other Islamic financial institutions. Whereas zakat accounting standards in Indonesia are not for business entities but for zakat institutions such as BAZNAS and LAZ (Adnan, 2009). According to a staff of religious ministry who is in charge of the zakat field, not all BAZNAS can implement the financial statements based on PSAK 109. This is caused by the weakness of human resource capability especially in accounting field. However, BAZNAS Pekanbaru is one of the exceptions, because BAZNAS Pekanbaru has made a financial report based on PSAK zakat 109 from 2011 to now (Megawati, 2015).

\section{Method}

Researcher used interview and observation to explore implementation of auditing in BAZNAS Riau province and BAZNAS Pekanbaru. Semi structure interview is choosen because to get more and deeply information. Key informant are the Commisioner Head and Manager of BAZNAS Riau province and BAZNAS Pekanbaru and some staff of the Ministry of Religion in zakat departement. Each of informant took 30 minutes until 2 hours interview process. The question about condition of audit in BAZNAS categorized with 3 theme. There are internal audit, financial audit and sharia audit. Data Anaysis used descriptive analysis. Researcher capture words and then interprete meaning.

\section{Result and Discussion}

\section{Internal Audit}

Internal audit is an independent and objective activity, providing assurance and insurance to an organization in terms of the degree of control 
held over operations, it guides it to improve operations and contributes to adding value (Daniela, 2013). The internal auditor's current task is increasingly complex because it is responsible for almost everything: for example identifying potential risks so as to prevent fraud and mismanagement by management (Ji, $\mathrm{Lu}$ and $\mathrm{Qu}, 2017)$. 'Internal audit is initially dedicated to accounting problems, but now it has become a powerful tool to detect the main risks of organizations' (Munteanu, 2014). In addition, the internal auditor also provides recommendations for improvement and efficiency of the process of organizational activities. This would enable him or her to get access and information and also can communicate the findings and recommendations. It would be uncomfortable to work if the internal auditor positiones him or herself as a police officer in his or her organization. Not much research on zakat or on internal audit in zakat Institutions has been done. The results of the study are mentioned that Internal control system and amil zakat's competence are proven to have significant influence on financial reporting quality partially and simultaneously. To increase public trust, amil zakat institutions should focus on increasing financial reporting quality, by increasing the effectiveness of internal control system and amil zakat's competence. So the zakat realization can be maximal. (Naz'aina, 2015)

In 2017, BAZNAS Pekanbaru has appointed a team that serves as an internal auditor. Each of them has a different focus of sharia audits, financial audits and performance audits. This team works temporary with output in the form of assessment reports and recommendations. According to the author of this paper, it is a good start and can be used as preparation of external audit. Ideally, the internal auditor should work as permanently as the opinion Petrascu (2013). Internal auditors are permanent employees of the entity or the General Shareholders Assembly. The possibility of employing specialized companies, by conclusion of service contracts, is not a subject being ruled out.

For BAZNAS Riau province took the other option, because of the head commissioner as accountant and auditor experience, he included as internal auditor. BAZNAS Riau province today has a small number of employee, so for 
efficiency of the cost. Besides the head commissioner still have time to do verification of each transaction. In Indonesia he said that only four head commissioner BAZNAS has accounting background. It is crucial for BAZNAS today to more focused on accounting report as transparency. In one year period of new commissioner duty, BAZNAS Riau Province need 6 month to transition from manual documented system to computerized.

\section{Financial Audit}

Under the regulation No. 23 of 2011, zakat institutions's financial statements should be audited by a public accounting firm. For small organizations the cost to pay for the services of public accountants is considered burden some (Mahzan, 2014).

Actually, in the last two years, BAZNAS Pekanbaru has been preparing to audit its financial statements, but still underconsideration of fees for services of public accountant office. Fortunately, the Obligation to audit the financial statements of BAZNAS in 2017 is for the provincial BAZNAS while BAZNAS of districts/cities, such as BAZNAS Pekanbaru financial audit obligations in the next year ie 2018. It means BAZNAS Pekanbaru still have the opportunity to prepare the budget, especially for the fee public accountant office.

BAZNAS Riau province which new human resources to be commissioner since Juni 2016 did many things such as fixing of documentation system and made financial report based on PSAK 109. Beside of collecting and distributing zakat fund, BAZNAS province also have duty to guide and supervise BAZNAS district. Based on Rakornas (National meeting) BAZNAS in Indonesia, $70 \%$ of duties is to guide and supervise and the remain is to collect and distribute zakat fund.

There are 12 BAZNAS district in Riau province. Today BAZNAS Riau province still focused on guidance BAZNAS district to make report according to PSAK 109. It will take long time to give accounting skill for not accounting background. 


\section{Sharia Audit}

The need for sharia audits is initially for sharia financial institutions that first developed rapidly in modern times compared to zakat institutions. In 2011 Dubai Islamic Bank stated that Islamic banks and Islamic finance industry are the fastest growing financial institution in the world's economic sector (Yaacob, 2012). Although if compared with conventional banks sharia financial system is still in the early stages of development.

Furthermore, Yaacob (2012) offers Hisbah as an independent sharia auditor. In the early period, the institution of Hisbah provided the role as the inspectorate of the 'market'. This is because it is considired as sharia supervisory councils in sharia financial institutions. Today it will be difficult to be independent if they are appointed and paid by the organization concerned.

Meanwhile, based on Government Regulation no. 14 year 2014, zakat institutions in sharia is audited by ministry of religious affairs. The independent auditor problem as described above may not occur because BAZNAS does not need to pay the auditor. But the question is: who is the sharia auditor in question and how the technical implementation? Therefore it is still required more detailed rules to determine it. A draft discussion has been conducted, and a strong candidate as a sharia auditor is the Inspektorat Jenderal of the Ministry of Religious Affairs. Inspektorat jenderal of Ministry of Religious Affairs has been doing the main duty as an internal auditor of the ministry of religion.

Until now we are still waiting for the passing of the regulation which is very likely taking a long time to be applied. The next question is what is the preparation of General Inspectorate of Ministry of Religious Affairs (Inspektorat JenderaI) to be able to carry out this additional task especially during this Irjen felt to have a very limited number of auditor personnel. Another question that is also very important is how the ability of the General Inspectorate as a sharia auditor because the competence of sharia auditors should have a good knowledge in accounting, finance, audit and jurisprudence (Islamic law). On the one hand, many are familiar with accounting, auditing 
and finance. On the other hand, there are only limited number of experts in fiqh (Islamic law) with these four competencies. Sharia finance expert also need to know about fatwas from DSN-MUI who authorize Islamic law in Indonesia and to know about zakat regulation such as Undang-undang (UU), Peraturan pemerintah (PP), Keputusan Menteri Agama (KMA), Peraturan Direktur Jenderal and Peraturan BAZNAS (Perbaznas).

Some concerns in sharia audits at zakat institutions are ensuring the collection of zakat, managing and distributing zakat in accordance with the principles of sharia. In collection instrument include about muzakki receipt of pay paper, zakat institution receipt halal (legalized wealth/fund) or not from money laundry. It also ensures the use of amil rights (operational funds for zakat institutions) has been done in accordance with the principles of sharia and zakat institutions not take more than $1 / 8$ in zakat total $(1 / 8$ are fairness portion for amil fund). In distribution instrument include zakat institution ensure the zakat recipient are the right people based on Qur'an criteria and to make sure the zakat fund not in bank account more than 1 year.

In addition, sharia-based financial system prohibits bank interest because it includes riba. Riba is one of the big sins in Islam. In fact, BAZNAS Riau province and BAZNAS Pekanbaru have an account in a conventional bank on the grounds that the account is a temporary holding account because muzakki from government employees has a salary account in the conventional bank. Other transactions continue to use sharia bank. According to researcher, the condition of BAZNAS is understandable as Islamic banks also have accounts in conventional banks for interbank payment traffic such as clearing. Moreover head commissioner argue that zakat institutions still have conventional bank account not to be prime instrument for sharia audit.

\section{Conclusion}

The functions of internal auditors of BAZNAS Pekanbaru and BAZNAS Riau province have been running, but not yet ideal as it should be. BAZNAS Pekanbaru appoints a team of internal auditors working in a certain period 
only. Considering the small organizational structure, the functions of BAZNAS Riau province internal auditors are directly implemented by the chairman. It is also bacause the capacity and background of accounting education owned by the chairman. The high cost of public accountant audit makes BAZNAS Pekanbaru has not conducted an external audit. Yet, BAZNAS Riau Province has been audited by public accountant office since the beginning of performance for the management period of 2016 till 2021. The sharia auditors do not exist yet. The government should issue sharia auditor regulation and this will be take time to be implemented. And are still waiting for the issuance of detailed regulations regarding the implementation of sharia audits.

\section{References}

Abozaid, A. (2016). The Internal Challenges Facing Islamic Finance Industry. International Journal of Islamic and Middle Eastern Finance and Management, Vol. 9 (2): 222-235.

Adnan, M. A. and Bakar, N. B. A. (2009). Accounting Treatment for Corporate Zakat: a Critical Review. International Journal of Islamic and Middle Eastern Finance and Management, Vol. 2 (1): 32-45.

Alexakis, C., and Tsikouras, A. (2009). Islamic Finance: Regulatory Framework-Challenges Lying Ahead. International Journal of Islamic and Middle Eastern Finance and Management, Vol. 2 (2): 90-104.

Beik, et al. (2014). Towards an Establishment of an Efficient and Sound Zakat System. Presented in the Working Group of Zakat Core Principles.

Daniela, P. and Attila, T. (2013). Internal Audit Versus Internal Control and Coaching. Procedia Economis and Finance, Vol. 6: 694-702.

Embong, M. R., Taha, R., and Nor, M. N. M. (2013). Role of Zakat to Eradicate Poverty in Malaysia. Jurnal Pengurusan, Vol. 39: 141-150.

Firdaus, M. et al. (2012). Economic Estimation and Determination of Zakat Potential in Indonesia. IRTI Working Paper Series 1433-07.

Gusfahmi. (2007). Pajak Menurut Syariah. Jakarta: PT. Raja Grafindo Persada.

Hafidhuddin D. (2011). Peran Strategis Organisasi Zakat dalam Menguatkan Zakat di Dunia. Jurnal Al infaq, Vol. 2 (1): 1-4

Hayeeharasah, F., Sehvises, S., and Ropha, H. (2013). The Timeline of Zakah. Procedia Social and Behavioral Sciences: 2-7. 
Ji, X., Lu, L., and Qu, W. (2017). Voluntary Disclosure of Internal Control Weakness and Earning Quality: Evidence from China. The International Journal of Accounting, Vol. 52(1): 27-44.

Khalifa, H., Alkdai, H., and Hanefah, M.M. (2012). Audit Committe Characteristic and Earnings Management in Malaysian Shariacompliant Companies. Business and Management Review: 52-61.

Kementerian Agama RI Direktorat Jenderal Bimbingan Masyarakat Islam. (2012). Panduan Organisasi Pengelola Zakat. Jakarta: Kementerian Agama RI.

Mahzan, N. and Yan, C. M. (2014). Harnessing the Benefits of Corporate Governance and Internal Audit: Advice to SME. Procedia-Social Behavioral sciences, Vol. 115: 156-165.

Megawati, D., and Trisnawati, F. (2015). Penerapan PSAK 109 tentang Akuntansi Zakat dan Infak/Sedekah pada BAZNAS Pekanbaru. Kutubkhanah, Vol. 17 (1): 40-59.

Munteanu, V. and Zaharia, D. L. (2014). Current Trends in Internal Audit. Procedia-Social and Behavioral Sciences, Vol. 116: 2239-2242.

Naz'aina. (2015). The Effect of Internal Control System and Amil Competence on the Financial Quality at Zakat Management Institution Active Member of Zakat Forum in Special Capital City Region Jakarta and West Java Provinces. Procedia- Social Behavioral Sciences: 753-760.

Nurzaman, M. S. (2010). Zakat and Human Development: An Empirical Analysis on Poverty Alleviation in Jakarta, Indonesia. Presented on 8th International Conference on Islamic Economics and Finance.

Qardawi, Y. (2004). Hukum Zakat. Pustaka Litera Antar Nusa.

Saad, R. A. S., Aziz, N. M. A., and Sawandi, N. (2014). Islamic Accountability Framework in the Zakat Funds Management. Procedia Social and Behavioral Sciences, Vol. 164: 508 - 515.

Wahab, N. A. and Rahman A. R. A. (2011). A Framework to Analyse the Efficiency and Governance of Zakat Institutions. Journal of Islamic Accounting and Business Research, Vol. 2(1): 43-62.

Yaacob, H. (2012). Issues and Challenges of Shari'ah Audit in islamic Financial Institutions: A Contemporary View. Presented on 3rd International Conference on Business and Economic Research. Bandung, Indonesia: 26692676.

Yusoff, M.B., and Densumite, S. (2012). Zakat Distribution and Growth in The Federal Territory of Malaysia. Journal of Economic and Behavioral Studies, Vol. 4 (8): 449-456. 